\title{
Exploitation of Children as a Crime against Human Rights
}

\author{
Moh. Indra Bangsawan
}

\begin{abstract}
Children are a part of the family and also the mandate once the grace of God Almighty, who should always be kept because in him the inherent dignity and rights as a human being which must be upheld. The phenomenon of the spread street children in Indonesia is a complex social problem because they are in a condition that is not clear condition in the future, one of which is the exploitation of children constitute extortion or withdrawal of benefit to children unreasonably. In Indonesia, child rights are part of human rights contained in the Constitution of 1945 section 28A to 28J, The United Nations Convention on the Rights of the Child and chapter 16 the Child Protection Act No. 35 of 2014 concerning amendments to the Law Decree No. 23 of 2003 Section III, chapter 4 to chapter 19 about Rights of the Child. Exploitation of children is an act that arise due to economic factors (poverty), environment, and domestic violence (domestic violence). The impact on the exploitation of child labor can cause a variety of disorders in children both physically and mentally is also bad for society. Therefore, parents should be able to perform their duties as parents to their children as compassionate and not depriving children, including making them as beggars, and the government must first improve the nation's economy. When the economy is good, then the phenomenon of street children over time will gradually disappear.
\end{abstract}

Keywords - Exploitation of children, street children, human rights.

\section{INTRODUCTION}

Children are also human and therefore respect the human rights of children as well as respect for human rights. Smith even reinforce that perfectly, precisely overall international human rights instruments that are in the "heart" of rights. Unfortunately, the facts still show, children including some of the most vulnerable groups for violence. Every child has rights, as rights possessed by adults, not many who think and want to do a concrete measures to protect children's rights review. The individual child is mature yet Good Operates Physical, and especially social life [1]. Children are a part of the family and also the mandate once the grace of God Almighty, who should always be kept because in her inherent dignity, dignity and rights as a human being which must be upheld [2]. In addition, Children's is an integral part of human survival and sustainability of the entire nation. Indonesia's constitution, the child has a strategic role that explicitly stated that the state guarantees the right of every child to live, grow, and develop as well as protection from violence and discrimination. Therefore, the best interests of the child should be lived as the best interests of the survival of humanity. The consequences of the provisions of Article 28B of the Constitution of the Republic of Indonesia 1945 should be followed up by making government policies that

Faculty of Law, University of Muhammadiyah Surakarta, Indonesia mibsambi@gmail.com. aim to protect Children [3]. Article 59 of Law No. 35 of 2014 on the amendment of Law No. 23 of 2002 on the Protection of the Child states that "Government, Local Government, and other state agencies shall be responsible and responsible for providing the Special Protection to Children. Children in emergency situations, child in conflict with the law, the Son of minorities and isolated, Children who are economically and / or sexual, child victims of drug abuse, alcohol, psychotropic and other addictive substances, child victims of pornography, Children with HIV / AIDS, child abduction, sale and / or trafficking, child victims of violence physical and / or psychological, child victims of sexual crimes, child victims of the terrorist network, child Disability, child victims of abuse and neglect, child behavior socially deviant, and Children who are victims of stigmatization of labeling associated with the condition of man His parents ".

The phenomenon of proliferation of street children in Indonesia is a complex social problem.Life became street children is indeed not a pleasant choice, because they are in a condition that is not potentially future is clear, and their existence does not become "problem" for many parties, family, society and the State. However, attention to the fate of street children seems to have not so great and solutif. But they are our brothers. They are the Trustees of God which must be protected, guaranteed his rights, so it grows into an adult human is beneficial, civilized and potentially future bright. Talking about the rights of the child, there were four rounds of international community over recognition of the rights of the child, namely (1) the right to survival; (2) the right to protection; (3) the right to tumbuh-kembang; (4) the right to participate [4]. Child exploitation is a part of the crime against human rights because they proved to be an unlawful behavior and violate social norms, so that the people are against it [5].

\section{METHOD}

Research methods this comparative research using the method of searching for answers to fundamentally about cause and effect, by analysing the factors cause the occurrence or appearance of a particular phenomenon, and is ex post facto Means, data collected after all events collected has been completed in progress. Researchers can see the result of a phenomenon and a causal relationship of test data available [6].

\section{DISCUSSION}

Marginal, vulnerable and exploitative terms is very appropriate to describe the conditions and lives of street children. Marginal because they are doing the kind of work that is not clearly the level of his career, underappreciated, and generally also not promising any prospect in the near future. 
Vulnerable because of risks that must be due to long working hours actually in terms of health or social services is very vulnerable. As for the so-called exploitative because they usually have a "bargaining" very weak, subordinate, and tends to be the object of arbitrary treatment of the act of thugs or local police officers who are not responsible. As part of "child labor", the street children themselves are not a homogenous group they are quite diverse and can be distinguished on the basis of his work, his relationship with a parent or adult nearby because of the time and type of activities in the street as well as gender. Based on the results of the study field, street children generally distinguished in three groups. First of children on the street and then the Second Children of the street and the third is children from the Family of the street [7].

Children on the street, children who have economic activities as working children in the street, but still has a strong relationship with their parents, most of their income on the street is given to parents. the function of street children In this category is to help strengthen their economic buffer for the load and the pressure that must be borne poverty can not be solved alone by his parents. The second is Children of the street, children who participate fully in the streets both socially and economically, some of them still have a relationship with the parents but the frequency of their meetings erratic many of them are children who for some reason are usually violent or run away from home. various studies show that children In this category are very vulnerable to mistreatment both socially emotionally physically and sexually. The third is Children from Family of the street, children from families living on the streets even though these children have family ties are strong enough but live they oscillate from one place to another with all the risks One important feature of this category is the view of the street life since childhood still in its infancy, in Indonesia this category easily found in various under bridges, houses wild along railroad tracks and so although quantitatively the amount is not certain. Based on data from the Center for Data and Information Ministry of Social Welfare in the number of street children throughout Indonesia as a child in 2006 as many as 232 894, 159 230 children in 2010, 67607 children in 2011, and by 2015 as many as 33,400 children [8]

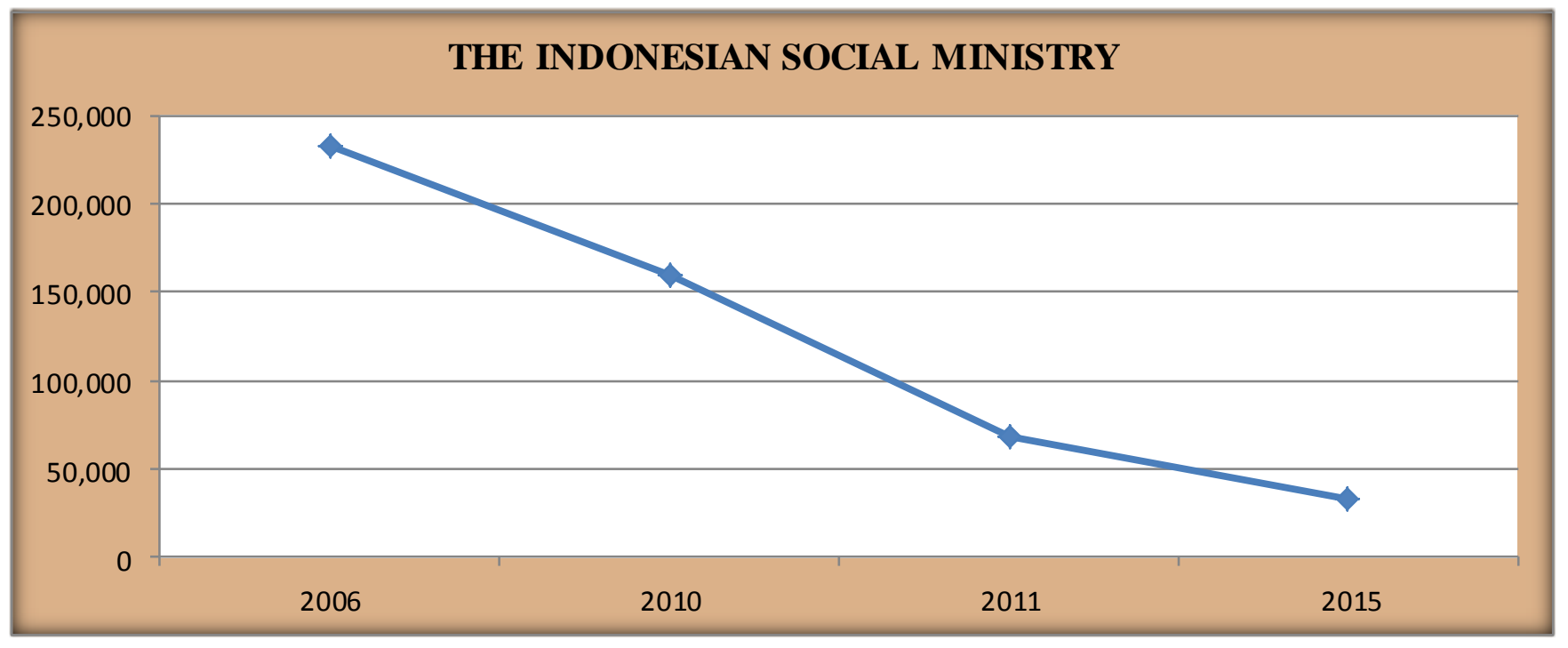

(Source of Data and Information Center Ministry of Social Welfare in 2016)

The importance of human rights protection peaked in 1948 when the United Nations (UN) proclaimed a Declaration of Human Rights (UDHR) impressively describes "rights inalienable and inviolable for all members of the human", the declaration marks a milestone in a moral in the history of the community of nations [9]. Normatively duly fulfilled all the needs of children in accordance with their rights, but there are still many children who are not being met right because it does not get the attention of parents so there are many children who have to live with finding money on the street as street children. Even a few of them in the exploitation by his parents to find the money to meet the needs of family life. Exploitation is extortion, exploitation, utilization, withdrawal unfair advantage. Child exploitation is extortion or withdrawal of benefit to children are not fair. Until now the issue of child labor is no longer about child labor itself, but rather has been the exploitation of children

TABLE 1. PROBLEMS FACED BY STREET CHILDREN

\begin{tabular}{|c|c|}
\hline Aspect & Problems Encountered \\
\hline Education & $\begin{array}{l}\text { Most dropouts because time ran out in } \\
\text { the street }\end{array}$ \\
\hline Intimidation & $\begin{array}{l}\text { Become targets of violence older } \\
\text { street children, another group, the } \\
\text { clerk, and raids }\end{array}$ \\
\hline $\begin{array}{l}\text { Abuse of drugs and addictive } \\
\text { substances. }\end{array}$ & $\begin{array}{l}\text { Drugs, booze, pills and other } \\
\text { sedatives }\end{array}$ \\
\hline Health & $\begin{array}{l}\text { Prone skin diseases, sexually } \\
\text { transmitted diseases, gonorrhea, and } \\
\text { lung }\end{array}$ \\
\hline Residence & $\begin{array}{l}\text { Generally, in any place in shacks or in } \\
\text { slums }\end{array}$ \\
\hline Job risk & Hit, the impact of trash \\
\hline Relationships with family & $\begin{array}{l}\text { Generally tenuous, and even } \\
\text { completely unrelated }\end{array}$ \\
\hline Food & $\begin{array}{l}\text { Potluck, sometimes crying out of } \\
\text { the trash, sometimes buy }\end{array}$ \\
\hline
\end{tabular}
or putting children in dangerous environments [10]. 
The problem of street children is not a simple thing to be faced, but it takes a certain approaches that can then be used as a part in addressing the problems of street children are caused by the exploitation crimes against children. Therefore, the Indonesian government has made efforts to realize Indonesian Street Children Free 2017 is a social movement launched by the Minister of Social Affairs on January 27, 2016. Towards Indonesia Free Street Children program in 2017 is a continuation Jakarta and Indonesian Street Children Free Street Children in 2011-2014. This program is the continuous efforts that need to be done in order for the street children no longer do economic and activity or life on the road, but had to return to the community, parents and family back together, back to school, as well as the family's social and economic support in order to be empowered.

TABLE II. APPROACH IN HANDLING CHILD EXPLOITATION

\begin{tabular}{|c|c|c|}
\hline Grouping Children & $\begin{array}{c}\text { Approach the } \\
\text { Program Strategy }\end{array}$ & $\begin{array}{c}\text { Intervention } \\
\text { Functions }\end{array}$ \\
\hline $\begin{array}{l}\text { Children who are still } \\
\text { in contact or live with } \\
\text { their parents }\end{array}$ & $\begin{array}{c}\text { Community } \\
\text { Based }\end{array}$ & Preventive \\
\hline $\begin{array}{c}\text { Children who still } \\
\text { have family in the family, } \\
\text { but is rarely associated / } \\
\text { living with their parents }\end{array}$ & Street Based & Protection \\
\hline $\begin{array}{l}\text { Kids marginalized / } \\
\text { end relationships with } \\
\text { family / parents }\end{array}$ & Centre Based & Rehabilitation \\
\hline
\end{tabular}

\section{IV.CONCLUSION}

Children are also human and therefore respect the human rights of children as well as respect for human rights. Smith even reinforce that perfectly, precisely overall international human rights instruments that are in the "heart" of rights. Unfortunately, the facts still show, children including some of the most vulnerable groups for violence. Every child has rights, as rights possessed by adults, not many who think and want to do a concrete measures to protect children's rights review. The individual child is mature yet Good Operates Physical, and especially social life. Exploitation (extortion, exploitation, utilization, withdrawal unfair advantage) against children is part of a crime against human rights because it proved to be a behavior that violate the law and violate social norms, so that the people are against it. Normatively duly fulfilled all the needs of children in accordance with their rights, but there are still many children who are not being met right because it does not get the attention of parents so there are many children who have to live with finding money on the street as street children. Even a few of them in the exploitation by his parents to find the money to meet the needs of family life. Problems exploitation of children is not a simple thing to deal with, but it takes a certain approaches that can then be used as a part in addressing the problems caused by ekpsloitasi crimes against children. The programs issued by the Indonesian government will be able to reduce the rate of exploitation of children, especially street children. The program seeks to continue to do so as street children are no longer doing economic activity and or living on the street, but had to return to the community, back in with his parents and family, back to school, and their families receive social and economic support so helpless.

\section{SUGGESTION}

The prevention of the proliferation of acts of exploitation of children is an obligation for the entire community. Protecting the rights of children as rights of manuisa to the impact of the crime of child exploitation is also our duty together. All components of the nation in this case the government and the whole society should establish a liaison integrated with the community as part of the component countries. The determination to guarantee the protection and rehabilitation of victims of child exploitation crimes and increase their sanctions against perpetrators of child exploitation crimes mover is a concrete solution based on considerations that have been described in this paper in order to safeguard the survival of the young generation in the future.

\section{ACKNOWLEDGEMENTS}

Praise me extend this presence of God as with grace, and his guidance I can finish a paper on Exploitation Of Children As A Crime Against Human Rights are probably still contained many flaws in it. And also I thank the Committee for joint international confereence event organizers who have held this International Conference on Studies in Arts, Humanities and Social Sciences. I really hope this paper could be useful in order to increase our knowledge and insights about the social Arts, Humanities and Social Sciences. I also realized that in this paper there are shortages and away from word perfect. Therefore, I hope the existence of criticism, suggestions and proposals for the sake of improvements to the paper that I had made in the days to come, considering nothing is perfect without the advice of building.

\section{REFERENCES}

[1] Harahap Imam Safruddin, 2016, "Perlindungan Hukum Terhadap Anak Korban Kejahatan Seksual dalam Perspektif Hukum Progresif”, Jurnal Media Hukum, Vol. 23 No.1

[2] Soekanto, Soerjono, 2004, “ Sosiologi Keluarga Tentang Ikhwal Keluarga Remaja dan Anak" Jakarta: Rineka Cipta.

[3] Ariani Nevey Ariani, 2014, "Implementasi Undang-Undang Nomor 11 Tahun 2012 Tentang Sstem Peradilan Pidana Anak Dalam Upaya Melindungi Kepentingan Anak", Jurnal Media Hukum, Vol. 21 No.1

[4] Muhtaj Majda El, 2008, "Dimensi-Dimensi HAM : Mengurai Hak Ekonomi, Social, dan Budaya", Jakarta ; PT. Rajagrafindo

[5] Wahyuni Fitri, 2016, "Sanksi Pidana Pemerkosaan Terhadap Anak Menurut Hukum Pidana Positif dan Hukum Pidana Islam ", Jurnal Media Hukum, Vol. 23 No.1

[6] Nazir,Moh. 1998. “Metode Penelitian”. Jakarta: ghalia Indonesia.

[7] Suyanto Bagong, 2010, "Masalah Sosial Anak", Jakarta: Kencana Penada Media Group.

[8] Kementrian Sosial Republik Indonesia, 2016,"Anak Jalanan Rentan Eksploitasi" (online), (https://rehsos.kemsos. go.id/modules.php?name $=$ News\&file $=$ print $\&$ sid $=1954$, accessible on December 26 2016).

[9] Green Mind Community. 2009. “Teori dan Politik Hukum”. Yogyakarta: Total Media.

[10] Usman, Hardius and Nachrowi. 2004. "Pekerja Anak Di Indonesia (Kondisi Determinan dan Eksploitasi) Kajian Kualitatif", Jakarta: Gramedia. 